\begin{tabular}{lr}
\hline PRACE NAUKOWE UNIWERSYTETU EKONOMICZNEGO WE WROCLAWIU \\
RESEARCH PAPERS OF WROCLAW UNIVERSITY OF ECONOMICS & nr 498・2017 \\
\hline Nauki ekonomiczne w XXI wieku - wyzwania, dylematy, perspektywy & ISSN 1899-3192 \\
Międzynarodowe stosunki gospodarcze & e-ISSN 2392-0041
\end{tabular}

\title{
Edward Molendowski
}

Uniwersytet Ekonomiczny w Krakowie

e-mail: edward.molendowski@uek.krakow.pl

\section{CZYNNIKI DETERMINUJĄCE POZYCJE KONKURENCYJNĄ GOSPODARKI - POLSKA NA TLE NOWYCH PAŃSTW CZLONKOWSKICH UE*}

\section{FACTORS DETERMINING THE COMPETITIVE POSITION OF THE ECONOMY - POLAND IN COMPARISON TO THE NEW EU MEMBER STATES}

\author{
DOI: $10.15611 /$ pn.2017.498.19 \\ JEL Classification: E2, E6, F4, F5
}

\begin{abstract}
Streszczenie: Artykuł jest prezentacją wyników analizy, w ramach której podjęto próbę porównania zmian pozycji konkurencyjnej Polski na tle pozostałych nowych państw członkowskich Unii Europejskiej (UE-10) w okresie poakcesyjnym w latach 2004-2016. Ważną częścią tej analizy było określenie, które z czynników determinujących tę pozycję miały największy wpływ na zmiany w badanym okresie. Przyjęto hipotezę, że Polska wśród państw UE-10 należy do tych, w których w okresie poakcesyjnym międzynarodowa pozycja konkurencyjna uległa najbardziej wyraźnej poprawie. W badaniu zastosowano analizę danych wtórnych, dotyczących filarów konkurencyjności gospodarki, wyodrębnionych w raportach Global Competitiveness Report, opracowywanych przez Światowe Forum Ekonomiczne. Artykuł kończy zestawienie najważniejszych wniosków wynikających z prezentowanej analizy.
\end{abstract}

Słowa kluczowe: międzynarodowa konkurencyjność gospodarki, czynniki determinujące pozycję konkurencyjną gospodarki, efekty członkostwa w UE, Polska na tle nowych państw członkowskich.

Summary: The article presents the results of the analysis which attempted to compare the changes in the competitive position of Poland in comparison to the new Member States (EU-10) in the post-accession period 2004-2016. An important part of the analysis was to define which of the factors determining this position had the greatest influence on the changes in the analyzed period. The hypothesis is assumed that Poland is among the EU-10 countries where the varied effects of the membership are the most clearly visible. This has had a significant impact on the international competitive position of the economy. The study uses the analysis of secondary data on the competitiveness' pillars of the economy identified in the

* Publikacja została dofinansowana ze środków Narodowego Centrum Nauki, przyznanych na podstawie decyzji nr: DEC-2015/17/B/HS4/02075. 
reports of "Global Competitiveness Report", prepared by the World Economic Forum. The article ends with a summary of the most important conclusions of the presented analysis.

Keywords: international competitiveness of the economy, factors determining the competitive position of the economy, effects of EU membership, Poland in comparison to the new Member States.

\section{Wstęp}

Polska, podobnie jak pozostałe nowe państwa członkowskie UE, zanotowała w okresie poakcesyjnym wiele sukcesów i porażek. Akcesja stała się impulsem do kolejnych zmian rozpoczętych jeszcze na początku lat dziewięćdziesiątych XX w., a pierwsze lata członkostwa pozwoliły na zbudowanie w miarę trwałych i stabilnych podstaw dalszego rozwoju. Stały się one głównym czynnikiem poprawy międzynarodowej pozycji konkurencyjnej gospodarki.

Bazując na wynikach wcześniejszych analiz, przeprowadzonych przez innych badaczy, w badaniu prezentowanym w artykule przyjęto założenie, że we współczesnej gospodarce światowej do osiągnięcia celów rozwojowych gospodarki konieczne jest strategiczne budowanie pozycji międzynarodowej, uwzględniające: zdolność do identyfikacji i promocji ,sektorów przyszłości” [Sung 2006, s. 38-42], rozwój zasobów ludzkich [Cho, Moon 1998, s. 142], zdolności technologicznych oraz ich uwarunkowania instytucjonalne [Miozzo, Walsh 2006] czy też zdolność dostosowania do zmieniających się warunków zewnętrznych [Oziewicz 2007, s. 22-23]. Te „strategiczne zachowania” gospodarek można powiązać ze sobą „pod płaszczykiem" budowania makrokonkurencyjności.

Celem artykułu jest prezentacja wyników analizy zmierzającej do porównania zmian pozycji konkurencyjnej polskiej gospodarki oraz pozostałych nowych państw członkowskich (UE-10) w latach 2004-2016. W analizie podjęto też próbę określenia wpływu najważniejszych czynników (filarów) na pozycję konkurencyjną Polski i pozostałych badanych krajów. Przyjęto hipotezę, że Polska należy wśród państw UE-10 do tych, w których w okresie poakcesyjnym międzynarodowa pozycja konkurencyjna uległa najbardziej wyraźnej poprawie.

Ze względu na narzucone ograniczenia objętościowe artykułu analizę odniesiono do wskaźników prezentowanych w raportach Global Competitiveness Report, opracowywanych przez Światowe Forum Ekonomiczne. Raporty te należą do najbardziej kompleksowych i najczęściej cytowanych rankingów konkurencyjności międzynarodowej gospodarek.

Artykuł jest prezentacją części szerszych badań realizowanych w ramach grantu badawczego, przyznanego przez Narodowe Centrum Nauki. 


\section{Mierniki i metody pomiaru konkurencyjności międzynarodowej gospodarki}

„Kraje, tak jak korporacje międzynarodowe, rywalizują na światowych rynkach”. Ta prowokacyjna teza B. Clintona, wygłoszona w 1993 roku, od lat rozpala ożywione dyskusje [Dunn 1994; Thurow 1994; Krugman 1994, 1996a; Wziątek-Kubiak 2004; Olczyk 2008; Aigigner 2006], sprzyjając tworzeniu wielu rankingów i porównań pozycji poszczególnych krajów w ramach gospodarki globalnej (szerzej zob. [Żmuda, Molendowski 2016]).

Ocena konkurencyjności międzynarodowej gospodarki polega na określeniu jej pozycji konkurencyjnej [Bossak 2000] lub zdolności konkurencyjnej gospodarki [Misala 2008]. W ostatnich latach mamy do czynienia $\mathrm{z}$ wieloma miernikami międzynarodowej konkurencyjności gospodarki narodowej, a zarazem metodami jej pomiaru. Dotyczy to zarówno mierzenia międzynarodowej zdolności konkurencyjnej gospodarki narodowej, jak i jej międzynarodowej pozycji konkurencyjnej w danym okresie. Determinanty określające konkurencyjność poszczególnych krajów stały się przedmiotem analiz wielu badaczy i ośrodków międzynarodowych.

Jednym z nich jest Międzynarodowy Instytut Zarządzania Rozwojem (IMD). Wyniki swych badań publikuje w corocznych raportach World Competitiveness Yearbook, obejmujących kilkadziesiąt krajów. Również Bank Światowy sporządza od 2004 roku coroczne raporty Doing Business, poświęcone analizie warunków prowadzenia działalności gospodarczej w badanych krajach. Stosunkowo często do oceny międzynarodowej zdolności konkurencyjnej gospodarki wykorzystuje się wskaźnik zaufania inwestorów zagranicznych (Foreign Direct Investment Confidence Index), sporządzany corocznie przez firmę konsultingową A.T. Kearney. Miarą międzynarodowej zdolności konkurencyjnej kraju jest także publikowany corocznie przez UNDP wskaźnik rozwoju społecznego (Human Development Index - HDI), będący syntetyczną miarą jakości życia w danym kraju.

W ostatnich latach jednym z najbardziej kompleksowych i najczęściej cytowanych jest ranking konkurencyjności międzynarodowej gospodarek The Global Competitiveness Report. Jest on rezultatem corocznego badania porównawczego warunków rozwoju gospodarczego krajów, prowadzonego przez Światowe Forum Ekonomiczne ${ }^{1}$.

\footnotetext{
${ }^{1}$ Raport ten został po raz pierwszy opublikowany w 1979 roku i jest systematycznie poszerzany o nowe państwa (w 2016 r. -138 krajów). Początkowo zawierał ranking „indeks konkurencyjności” (Competitiveness Index), opracowany pod kierownictwem prof. J. Sachsa, w którym wskazywano podstawy średnio- i długoterminowego szybkiego rozwoju gospodarczego. W 2000 r. zmieniono jego nazwę na indeks wzrostu konkurencyjności (Growth Competitiveness Index), dla odróżnienia od bieżącego indeksu mikroekonomicznej konkurencyjności, występującego pod różnymi nazwami w różnych raportach. W 2004 r. zastąpiono go przez globalny indeks konkurencyjności (Global Competitiveness Index). Jest on opracowany przez World Economic Forum we współpracy z profesorem X. Sala-i-Martinem z wykorzystaniem badań prof. M. Portera [WEF 2016, 2017].
} 


\section{Zmiany pozycji konkurencyjnej Polski na tle nowych państw członkowskich}

Wyniki badań konkurencyjności gospodarek przeprowadzone przez World Economic Forum (WEF) pozwalają stwierdzić, że pozycja i konkurencyjność polskiej gospodarki na arenie międzynarodowej była na początku lat 2000. (na tle nowych państw członkowskich UE) relatywnie niska.

Bazując na danych, których ilustracją są wykresy 1 oraz 2, można jednoznacznie stwierdzić, że w okresie poakcesyjnym (lata 2004-2016) pozycja Polski ulegała jednak istotnym zmianom. O ile w roku 2004 polska gospodarka pod względem konkurencyjności zajęła dopiero 60. pozycję (3,98 pkt), o tyle w kolejnych dwóch latach jej konkurencyjność została oceniona już znacznie korzystniej - 51. oraz 45. miejsce (odpowiednio 4 oraz 4,39 pkt). W okresie światowego kryzysu najbardziej niekorzystny wynik osiągnęła Polska w roku 2008, zajmując 53. miejsce (4,28 pkt) w rankingu. Kolejne dwa lata oznaczały wyraźną poprawę pozycji - 46. i 39. miejsce (4,33 oraz 4,51 pkt). W następnych czterech latach (2011-2015) konkurencyjność polskiej gospodarki oceniana była na podobnym poziomie. W latach 2011-2012 Polska zajmowała 41. miejsce (4,46 pkt) w rankingu, w latach 2013-2014 spadała o jedno miejsce $\mathrm{z}$ każdym rokiem. Z kolei w latach 2015-2016 znowu istotnie poprawiła swoją pozycję, by powrócić odpowiednio na 41. i 36 . miejsce $(4,49$ oraz 4,56 pkt). W rezultacie, w całym analizowanym okresie Polska poprawiła swoją pozycję w rankingu aż o 24 miejsca $(0,58$ pkt).

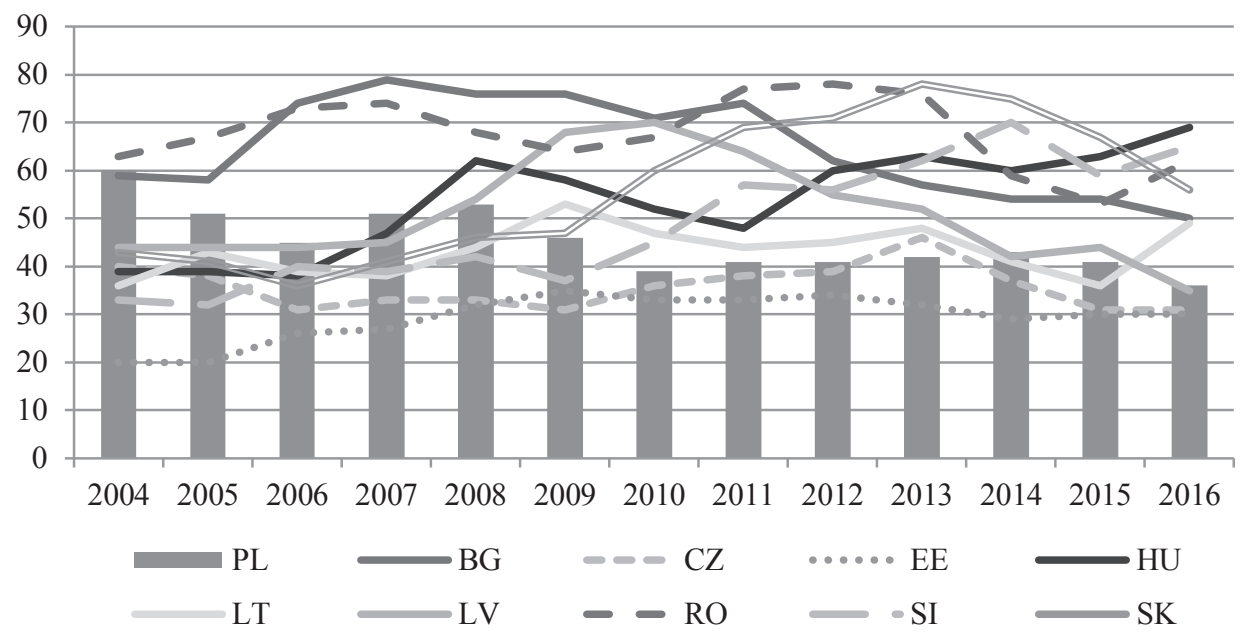

Rys. 1. Zmiany pozycji konkurencyjnej Polski na tle krajów UE-10 w badaniach prowadzonych przez World Economic Forum w latach 2004-2016

Źródło: opracowanie własne na podstawie [WEF 2016]. 


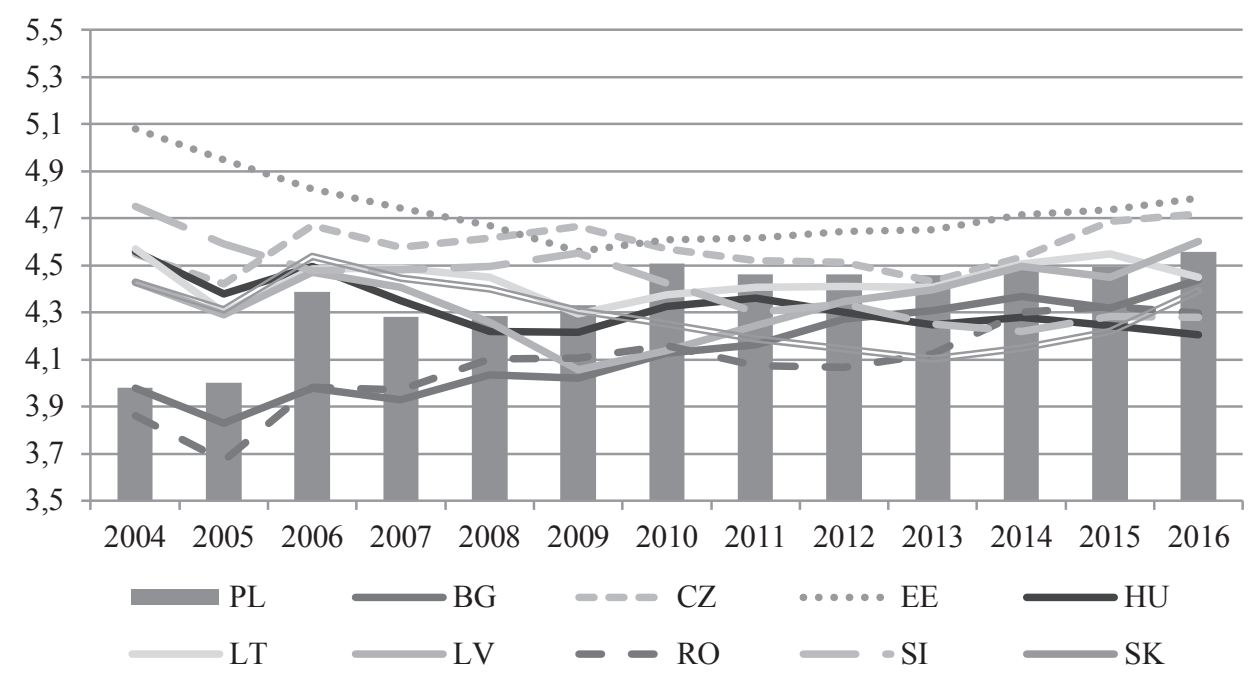

Rys. 2. Zmiany wartości wskaźnika GCI dla Polski na tle krajów UE-10 w latach 2004-2016 Źródło: opracowanie własne na podstawie [WEF 2016].

Jak pokazano na wykresach (rys. 1 oraz 2), trudno wskazać jednolitą tendencję w kształtowaniu pozycji konkurencyjnej polskiej gospodarki w całym okresie 2004-2016. W pierwszych latach po akcesji (2005-2006) nastąpiła wyraźna poprawa pozycji konkurencyjnej polskiej gospodarki. W latach 2007-2008 ta korzystna tendencja została odwrócona, ale w latach 2009-2010 miała miejsce ponownie poprawa. W efekcie tych zmian w rankingu Polski nastąpiła poprawa z 60. pozycji w $2004 \mathrm{r}$. do 39. pozycji w 2010 r. W następnych pięciu latach (2011-2015) nastąpiło jednak odwrócenie (lub zatrzymanie) tego korzystnego trendu. W 2016 r. miała miejsce kolejna istotna poprawa pozycji, co umożliwiło zajęcie już 36. miejsca w rankingu. Było to najkorzystniejsze miejsce w całym okresie poakcesyjnym.

Ważnym elementem prezentowanej analizy było porównanie wyników uzyskiwanych przez Polskę z wynikami pozostałych nowych państw członkowskich UE. Są to, jak wiadomo, kraje, które w okresie transformacji (po 1990 r.) zanotowały największe sukcesy gospodarcze spośród wszystkich krajów Europy Środkowo-Wschodniej. Akcesja do Unii Europejskiej stała się impulsem do trwałych zmian i zbudowania w miarę trwałych i stabilnych podstaw ich rozwoju. Jednakże w rankingach konkurencyjności uzyskiwały one dość zróżnicowane wyniki (por. tabela 1 oraz rys. 1 i 2). Na początku tego okresu konkurencyjność Polski (60. miejsce) była oceniana relatywnie najgorzej. Tylko Rumunia zajmowała dalsze (63.) miejsce, a Bułgaria podobnie znajdowała się na 59. miejscu. Pozycja Polski znacznie odbiegała od pozycji zajmowanej przez państwa Grupy Wyszehradzkiej (GW-4). Czechy, Węgry i Słowacja zajmowały wówczas znacznie wyższe pozycje (odpowiednio: 40., 
39. oraz 43. miejsce). O wiele korzystniejsze miejsca zajmowały też państwa bałtyckie. Estonia, Łotwa i Litwa otrzymały odpowiednio: 20., 36. oraz 44. miejsce w rankingu WEF.

W kolejnych latach, aż do roku 2007, Polska nadal zajmowała gorszą pozycję niż pozostałe kraje GW-4 oraz państwa bałtyckie. W 2008 r. Węgry, a w 2009 r. Słowacja, Łotwa i Litwa zajęły pozycję gorszą niż Polska. W latach 2010-2012 Polska zajmowała już wyższą pozycję niż 7 spośród 10 nowych państw członkowskich. Taka sytuacja utrzymała się do końca analizowanego okresu (2016 r.). W rezultacie w 2016 r. tylko Estonia, Czechy i Łotwa zajmowały wyższe pozycje niż Polska (odpowiednio: 30., 31. oraz 35.). W ten sposób Polska, uzyskując 36. miejsce, poprawiła (w porównaniu z badanymi krajami) swoją pozycję w rankingu w największym stopniu. Poza Polską swoją pozycję poprawiły tylko Czechy, Łotwa oraz Bułgaria.

Warto podkreślić, że analizując dane zilustrowane na wykresach (rys. 1 oraz 2), można jednoznacznie stwierdzić, że Polska zanotowała w latach 2004-2016 na tle badanych krajów największe sukcesy w poprawie międzynarodowej pozycji konkurencyjnej swej gospodarki. O ile w przypadku Polski w rankingu WEF nastąpiła poprawa aż o 24 pozycje (o 0,58 pkt), o tyle w przypadku Czech, Łotwy i Bułgarii poprawa wyniosła 9 pozycji (o 0,17 pkt dla Czech i Łotwy oraz o 0,46 pkt dla Bułgarii). Równocześnie 5 państw pogorszyło swoją pozycję: w tym Słowacja aż o 32 miejsca, Węgry - o 30 miejsc, Litwa i Słowenia - o 13 miejsc oraz Estonia - o 10 miejsc. To spowodowało, że Polska z kraju, który w 2004 r. zajmował jedną z najgorszych pozycji, stała się krajem o znacznie korzystniejszej pozycji w porównaniu z dwoma partnerami z Grupy Wyszehradzkiej (Słowacja, Węgry), jednym z państw bałtyckich (Litwa) oraz z Bułgarią, Rumunią i Słowenią. W rezultacie tych zmian Polska dołączyła w 2016 r. do liderów rankingu WEF spośród krajów UE-10, tj. Czech, Estonii oraz Litwy [Boguszewski 2016, s. 21-28].

\section{Czynniki determinujące pozycję konkurencyjną Polski na tle krajów UE-10}

Jak już wspomniano, rezultatem corocznego badania porównawczego warunków rozwoju gospodarczego krajów prowadzonego przez Światowe Forum Ekonomiczne jest ranking konkurencyjności międzynarodowej gospodarek The Global Competitiveness Report. Jest on obecnie (2016 r.) wyliczany na bazie 114 czynników, zestawionych w 12 filarach, które podzielono na 3 kategorie: podstawowe (basic requirements), poprawiające efektywność (efficiency enhancers) oraz innowacje i lokalne powiązania biznesowe (innovation and sophistication factors). Wykaz czynników, na bazie których określana jest pozycja konkurencyjna badanych krajów, zawiera tabela 1. 
Tabela 1. Klasyfikacja czynników determinujących pozycję konkurencyjną kraju wg Global Competitiveness Report

\begin{tabular}{|c|c|c|}
\hline \multicolumn{3}{|c|}{ GLOBALNY INDEKS KONKURENCYJNOŚCI } \\
\hline czynniki podstawowe & czynniki poprawiające efektywność & $\begin{array}{c}\text { innowacyjność i powiazania } \\
\text { sieciowe }\end{array}$ \\
\hline $\begin{array}{l}\text { Filar 1- Otoczenie } \\
\text { instytucjonalne } \\
\text { Filar } 2 \text { - Infrastruktura } \\
\text { Filar } 3 \text { - Otoczenie } \\
\text { makroekonomiczne } \\
\text { Filar 4 - Zdrowie i szkolnictwo } \\
\text { podstawowe }\end{array}$ & $\begin{array}{l}\text { Filar } 5 \text { - Szkolnictwo wyższe } \\
\text { i edukacja } \\
\text { Filar } 6 \text { - Efektywność rynku dóbr } \\
\text { Filar } 7 \text { - Efektywność rynku pracy } \\
\text { Filar } 8 \text { - Rozwój rynku finansowego } \\
\text { Filar } 9 \text { - Gotowość technologiczna } \\
\text { Filar } 10 \text { - Wielkość rynku }\end{array}$ & $\begin{array}{l}\text { Filar } 11 \text { - Kultura biznesu } \\
\text { Filar } 12 \text { - Innowacyjność }\end{array}$ \\
\hline $\begin{array}{l}\text { Rozwój determinowany } \\
\text { przez tradycyjne czynniki }\end{array}$ & $\begin{array}{l}\text { Rozwój determinowany } \\
\text { przez inwestycje }\end{array}$ & $\begin{array}{l}\text { Rozwój determinowany } \\
\text { przez innowacje }\end{array}$ \\
\hline
\end{tabular}

Źródło: opracowanie własne na podstawie [WEF 2016].

Warto podkreślić, że wśród czynników determinujących pozycję konkurencyjną kraju relatywnie największą wagę w badaniach prowadzonych przez WEF przypisano czynnikom sprzyjającym podnoszeniu efektywności. Z kolei czynnikom podstawowym nadano relatywnie dużą wagę w określaniu pozycji konkurencyjnej krajów o najniższym poziomie rozwoju gospodarczego [WEF 2016, s. 38].

Oczywiste jest, że w tego typu analizach szczególną rolę odgrywa badanie tendencji długookresowych. W prezentowanej analizie podjęto więc próbę zidentyfikowania najważniejszych tendencji, jakie charakteryzowały zmiany pozycji konkurencyjnej Polski na tle analizowanych krajów w 2016 r. w porównaniu z 2006 r. Zmiany te są widoczne przy porównaniu danych zestawionych w tabeli 2, których ilustracją są wykresy (rys. 3 i 4 ).

Z danych zestawionych w tabeli 2 wynika, że w 2006 r. najbardziej istotny wpływ na pozycję konkurencyjną Polski (4,39 pkt) miały czynniki podstawowe $(4,62 \mathrm{pkt}), \mathrm{w}$ tym zwłaszcza wielkość rynku, zdrowie i szkolnictwo podstawowe, oraz - w znacznie mniejszym stopniu - czynniki poprawiające efektywność $(4,33$ pkt), w tym głównie szkolnictwo wyższe i edukacja oraz efektywność rynku pracy. W najmniejszym stopniu na tę pozycję wpływały czynniki poprawiające innowacyjność (3,73 pkt).

Jak już wcześniej wykazano, w okresie do 2016 r. nastąpiła wyraźna poprawa oceny konkurencyjności polskiej gospodarki (do 4,49 pkt). Poprawa ta była możliwa głównie dzięki wyższej ocenie czynników podstawowych (4,91 pkt) oraz w mniejszym stopniu czynników proefektywnościowych (4,64 pkt). Warto podkreślić, że relatywnie większa poprawa nastąpiła jednak w grupie czynników proefektywnościowych (o $0,31 \mathrm{pkt}$ ), niż podstawowych (o $0,29 \mathrm{pkt}$ ). 
Tabela 2. Wpływ poszczególnych czynników na pozycję konkurencyjną krajów UE-10 w latach 2006 i $2016^{*}$

\begin{tabular}{|l|c|c|c|c|c|c|c|c|}
\hline \multirow{2}{*}{ Kraje } & \multicolumn{9}{|c|}{2006} & \multicolumn{5}{c|}{2016} \\
\cline { 2 - 10 } & ogółem & podstawowe & proefektywnościowe & proinnowacyjne & ogółem & podstawowe & proefektywnościowe & proinnowacyjne \\
\hline BG & $\mathbf{3 , 9 8}$ & 4,35 & 3,84 & 3,20 & $\mathbf{4 , 3 2}$ & 4,57 & 4,31 & 3,37 \\
\hline CZ & $\mathbf{4 , 6 7}$ & 4,94 & 4,59 & 4,39 & $\mathbf{4 , 6 9}$ & 5,26 & 4,78 & 4,14 \\
\hline EE & $\mathbf{4 , 8 2}$ & 5,28 & 4,69 & 4,03 & $\mathbf{4 , 7 4}$ & 5,60 & 4,74 & 4,15 \\
\hline HU & $\mathbf{4 , 4 9}$ & 4,71 & 4,48 & 4,06 & $\mathbf{4 , 2 5}$ & 4,67 & 4,31 & 3,57 \\
\hline LT & $\mathbf{4 , 4 9}$ & 4,91 & 4,28 & 3,83 & $\mathbf{4 , 5 5}$ & 5,14 & 4,59 & 4,02 \\
\hline LV & $\mathbf{4 , 4 7}$ & 4,84 & 4,35 & 3,59 & $\mathbf{4 , 4 5}$ & 5,10 & 4,56 & 3,69 \\
\hline PL & 4,39 & 4,62 & 4,33 & 3,73 & $\mathbf{4 , 4 9}$ & 4,91 & 4,64 & 3,70 \\
\hline RO & $\mathbf{3 , 9 8}$ & 4,08 & 4,00 & 3,51 & $\mathbf{4 , 3 2}$ & 4,55 & 4,37 & 3,48 \\
\hline SI & $\mathbf{4 , 4 8}$ & 5,18 & 4,42 & 4,11 & $\mathbf{4 , 2 8}$ & 4,90 & 4,21 & 3,99 \\
\hline SK & $\mathbf{4 , 5 4}$ & 4,76 & 4,50 & 3,82 & $\mathbf{4 , 2 2}$ & 4,73 & 4,34 & 3,68 \\
\hline
\end{tabular}

* Dane zestawione w tej tabeli obejmują okres tylko od roku 2006, gdyż w rankingach za poprzednie lata stosowano inną klasyfikację czynników determinujących pozycję konkurencyjną badanych krajów.

Źródło: opracowanie własne na podstawie [WEF 2016]. 


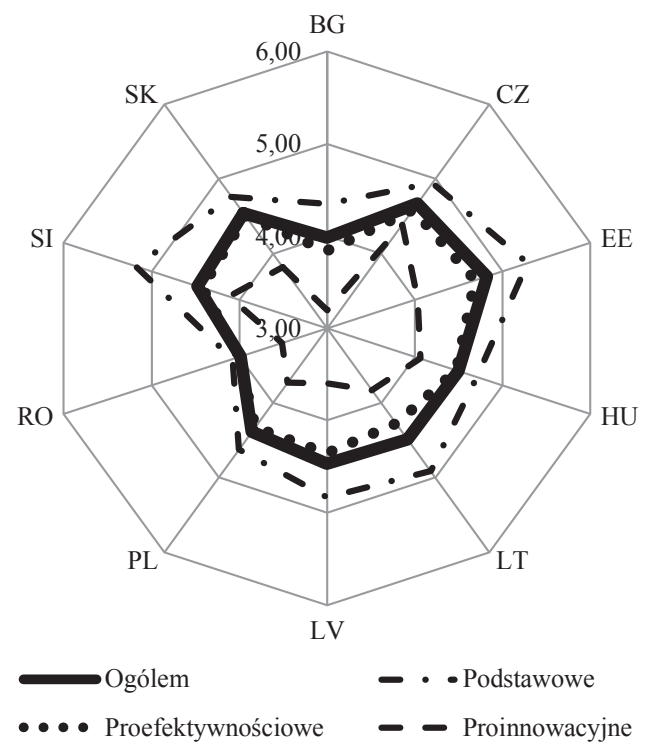

Rys. 3. Czynniki determinujące pozycję konkurencyjną Polski oraz pozostałych krajów UE-10 w 2006 r.

Źródło: opracowanie własne na podstawie danych z tabeli 2.

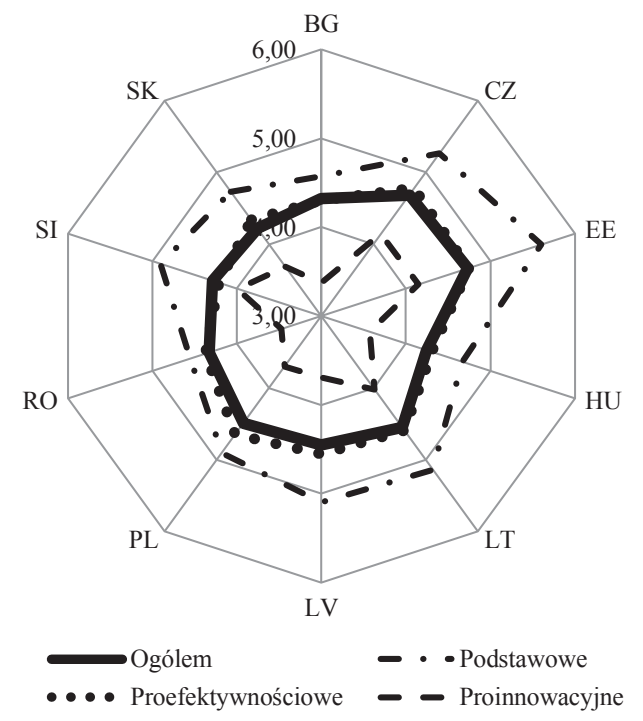

Rys. 4. Czynniki determinujące pozycję konkurencyjną Polski oraz pozostałych krajów UE-10 w 2016 r.

Źródło: opracowanie własne na podstawie danych z tabeli 2. 
Niestety, w grupie czynników proinnowacyjnych ocena Polski, relatywnie niska w 2006 r. (3,73 pkt), w okresie do 2016 r. uległa nawet niewielkiemu pogorszeniu $(3,7 \mathrm{pkt})$.

$\mathrm{Z}$ analizy danych zawartych w raportach WEF wynika również, że w badanym okresie nastąpiła poprawa pozycji konkurencyjnej Polski w przypadku większości (8 na 12) czynników ją determinujących. Zdecydowanie największa poprawa miała jednak miejsce w grupie czynników podstawowych, odgrywających relatywnie dużą rolę w określaniu pozycji konkurencyjnej krajów o najniższym poziomie rozwoju gospodarczego (otoczenie instytucjonalne - o 11 miejsc, infrastruktura - o 9 miejsc oraz otoczenie makroekonomiczne o 5 miejsc). W grupy czynników proefektywnościowych wyraźna poprawa miała miejsce tylko w przypadku rozwoju rynku finansowego (o 21 miejsc) oraz efektywności rynku dóbr (o 10 miejsc). Niestety, w grupie czynników proinnowacyjnych nie zanotowano żadnych sukcesów, nastąpiło tu wręcz wyraźne pogorszenie (aż o 21 miejsc). Warto też dodać, że równocześnie nastąpiło istotne pogorszenie pozycji konkurencyjne Polski w przypadku efektywności rynku pracy (aż o 40 miejsc) oraz zdrowia i szkolnictwa podstawowego (o 19 miejsc) [WEF 2015; WEF 2016].

Warto też podkreślić, że w przypadku Polski w porównaniu z pozostałymi państwami UE-10 nastąpiły w okresie poakcesyjnym relatywnie najbardziej korzystne zmiany w kształtowaniu pozycji konkurencyjnej. Jak to widać na rys. 3, w 2006 r. pozycja konkurencyjna Polski i wszystkich państw UE-10 była determinowana przez czynniki podstawowe (wartość wskaźnika GCI w grupie czynników podstawowych przekraczała jego wartość ogółem). Wartość wskaźnika GCI w grupie czynników proefektywnościowych oraz projakościowych była wówczas wyraźnie niższa niż wskaźnika ogółem.

Z kolei w roku 2016 (rys. 4) czynniki podstawowe nadal determinowały pozycję konkurencyjną wszystkich badanych krajów (wartości wskaźnika dla tej grupy znacznie przekraczały analogiczne wartości wyliczone dla pozostałych grup czynników. Jednakże rola czynników proefektywnościowych w przypadku Polski (oraz sześciu) spośród badanych krajów poprawiła się, chociaż tylko w niewielkim stopniu (wartości współczynnika dla tej grupy już nieznacznie przekraczały wartości wskaźnika GCI ogółem. Warto też podkreślić, że w przypadku Polski wartość wskaźnika w grupie czynników proefektywnościowych w 2016 r. była o 0,31 pkt wyższa niż w roku 2006. Podobną poprawę wśród analizowanych krajów zanotowały jeszcze tylko Bułgaria i Rumunia. Z kolei w grupie czynników proinnowacyjnych Polska, podobnie jak większość badanych krajów (z wyjątkiem Bułgarii, Estonii, Litwy i Łotwy), nie zanotowała żadnych sukcesów.

\section{Podsumowanie i wnioski}

Akcesja do Unii Europejskiej zapewniła Polsce i pozostałym krajom UE-10 szybki wzrost gospodarczy przy jednoczesnej restrukturyzacji i modernizacji. Miało to istotny wpływ na poprawę międzynarodowej pozycji konkurencyjnej gospodarki. 
Z zaprezentowanego w artykule przeglądu najważniejszych pozycji literatury wynika, że konkurencyjność gospodarki powinna być ujmowana w sposób dynamiczny, przez pryzmat rozwoju dostępnych (krajowych i zagranicznych) czynników produkcji, umiejętności wykorzystywania szans związanych z postępem globalizacji oraz zdolności dostosowawczych firm, sektorów i całej gospodarki do zmieniających się warunków otoczenia zewnętrznego, a w efekcie - realizacji celów rozwojowych. Takie ujęcie konkurencyjności gospodarki zostało zaadaptowane przez autorów raportów Global Competitiveness Report, opracowywanych przez badaczy skupionych wokół Światowego Forum Ekonomicznego.

$\mathrm{Z}$ analizy raportów World Economic Forum za lata 2004-2016 wynika jednoznacznie, że Polska zanotowała na tle nowych państw członkowskich (UE-10) największe sukcesy w poprawie międzynarodowej pozycji konkurencyjnej swej gospodarki. Na początku tego okresu konkurencyjność Polski (60. miejsce) była oceniana znacznie gorzej niż w przypadku 9 spośród 10 analizowanych krajów. Jednak w 2016 r. Polska stała się już krajem o korzystniejszej pozycji w porównaniu z większością badanych krajów. Wyprzedzały ją tylko nieznacznie: Estonia, Czechy i Łotwa. Warto też dodać, że w 2016 r. w porównaniu z 2004 r. aż pięć spośród analizowanych krajów pogorszyło swoją pozycję. Były to: Słowenia (aż o 32 miejsca), Węgry (o 30 miejsc), Słowacja i Litwa (o 13 miejsc) oraz Estonia (o 10 miejsc).

Badając wpływ poszczególnych czynników na kształtowanie międzynarodowej pozycji konkurencyjnej, należy stwierdzić, że sukcesy te Polska zawdzięcza poprawie oceny większości spośród nich. Ich wartości w 2016 r. były wyższe niż w $2006 \mathrm{r}$. aż w przypadku 9 (na 12) filarów. Zdecydowanie największa poprawa nastąpiła jednak w grupie czynników podstawowych (infrastruktura, otoczenie instytucjonalne, otoczenie makroekonomiczne). W grupie filarów proefektywnościowych wyraźna poprawa miała miejsce tylko w przypadku gotowości technologicznej, a nieznaczna w przypadku efektywności rynku dóbr oraz szkolnictwa wyższego. Niestety, w grupie czynników proinnowacyjnych nie zanotowano żadnych sukcesów.

Tak wysoki awans w przytaczanych raportach WEF przypisuje się w szczególności dynamicznemu wzrostowi PKB, zwłaszcza w okresie światowego kryzysu gospodarczego. Polska w całym badanym okresie poakcesyjnym wyróżniała się wśród nowych państw członkowskich UE najwyższym wskaźnikiem przyrostu PKB. Dzięki temu, pomimo odnotowanego pogorszenia stanu finansów publicznych, została ona uznana za jedną z najbardziej stabilnych makroekonomicznie gospodarek na kontynencie [Molendowski 2015, s. 5-18]. Tę korzystną zmianę pozycji Polski przypisuje się także relatywnie dobremu systemowi edukacyjnemu oraz posiadaniu dużego rynku wewnętrznego. Zauważono również korzyści wynikające z poprawy funkcjonowania administracji państwowej [WEF 2016].

Najważniejsze wyniki analizy zaprezentowane $\mathrm{w}$ artykule pozwalają na stwierdzenie, że w okresie poakcesyjnym Polska zanotowała na tle pozostałych nowych państw członkowskich UE relatywnie największe sukcesy w poprawie międzynarodowej pozycji konkurencyjnej swej gospodarki. Awans ten był jednakże rezul- 
tatem poprawy osiągniętej w zakresie czynników podstawowych determinujących tę pozycję. Znacznie mniejsza poprawa miała miejsce w zakresie czynników proefektywnościowych, chociaż (w porównaniu z pozostałymi krajami) osiągnięte rezultaty zasługują na wyróżnienie. Niestety, w grupie czynników proinnowacyjnych ocena dla Polski w roku 2016 była nawet gorsza niż w 2006 r. Można to uznać za największą słabość polskiej gospodarki. Taka sytuacja nie powinna się utrzymywać w dłuższej perspektywie. Oznacza to, że w najbliższych latach należy szczególną uwagę zwrócić na powstawanie i rozwój przedsiębiorstw innowacyjnych. Będzie to możliwe tylko przy zwiększeniu nakładów na sferę B+R. Nakłady te w Polsce w przeliczeniu na jednego mieszkańca (267 USD) w 2015 r. należały (jak dotychczas) do najniższych wśród państw Grupy Wyszehradzkiej i były też zdecydowanie niższe od średniej dla UE-28 oraz OECD [Odrobina 2017, s. 469]. Zwiększenie tych nakładów umożliwiłoby niezbędny rozwój potencjału naukowego, wprowadzenie nowych i poszerzenie już funkcjonujących programów podnoszących kwalifikacje zawodowe pracowników zatrudnionych w tych przedsiębiorstwach.

Zaprezentowane w artykule rozważania stanowić będą punkt wyjścia do dalszego etapu badań, w ramach którego przewiduje się szczegółową analizę czynników determinujących zmianę pozycji konkurencyjnej Polski na tle pozostałych nowych państw członkowskich UE.

\section{Literatura}

Aigigner K., 2006, Competitiveness: From a dangerous obsession to a welfare creating ability with positive externalities, Journal of Industry, Competition and Trade, no. 2, s. 161-177.

Boguszewski P., 2016, Globalny raport konkurencyjności 2016-17 Światowego Forum Ekonomicznego, NBP, Warszawa.

Bossak J., 2000, Międzynarodowa konkurencyjność gospodarki kraju i przedsiębiorstwa. Zagadnienia teoretyczne i metodologiczne, [w:] Bossak J., Bieńkowski W. (red.), Konkurencyjność gospodarki Polski w dobie integracji z Unia Europejska, Wydawnictwo SGH, Warszawa.

Cho D., Moon H., 1998, A nation's international competitiveness in different stages of economic development, Advances in Competitiveness Research, vol. 6, no. 1, s. 5-19.

Dunn M.H., 1994, Do nations compete economically? A critical comment on Prof. Krugman's essay, „Competitiveness: A dangerous obsession”, Intereconomics, November/December, s. 303-308.

Krugman P., 1994, Competiveness: A dangerous obsession, Foreign Affairs, vol. 73, no. 2, s. 28-44.

Miozzo M., Walsh V., 2006, International Competitiveness and Technological Change, Oxford University Press, New York.

Misala J., Misztal P., Młynarzewska I., Siek E., 2008, Międzynarodowa konkurencyjność gospodarki Polski w okresie 1990-2007, Politechnika Radomska, Radom.

Molendowski E., 2015, 10 Years of membership in the European Union-Poland in comparison with the Visegrad Group countries, Central European Review of Economics \& Finance, vol. 10, no. 4, s. 5-18.

Odrobina A., 2017, Bariery działalności badawczo-rozwojowej krajów Grupy Wyszehradzkiej, [w:] Maciejewski M., Wach K. (red.), Handel zagraniczny i biznes międzynarodowy we współczesnej gospodarce, Uniwersytet Ekonomiczny, Kraków.

Olczyk M., 2008, Konkurencyjność. Teoria i praktyka, CeDeWu, Warszawa. 
Oziewicz E., 2007, Dylematy rozwoju gospodarczego krajów Azji Poludniowo-Wschodniej na tle procesów globalizacyjnych, Wydawnictwo Naukowe Uniwersytetu Gdańskiego, Gdańsk.

Sung J., 2006. Exploring Economic Success of Singapore, Edward Elgar, Northampton.

Thurow L.C.,1994, Microchips, not potato chips, Foreign Affairs, vol. 73, s. 189-192.

WEF, 2015, The Global Competitiveness Report 2014-2015, World Economic Forum, Geneva.

WEF, 2016, The Global Competitiveness Report 2016-2017, World Economic Forum, Geneva.

Weresa M.A., 2008, Definicje, determinanty oraz sposoby pomiaru konkurencyjności krajów, Prace i Materiały, nr 284, s. 98-106.

Wziątek-Kubiak A., 2004, Kontrowersje wokót konkurencyjności w teorii ekonomii, Ekonomista, nr 6, s. 805-807.

Żmuda M., Molendowski E., 2016, W poszukiwaniu istoty konkurencyjności gospodarki narodowej: studium interdyscyplinarne, Finanse, Rynki Finansowe, Ubezpieczenia, nr 3 (81), s. 323-334. 